\title{
Estimating the growth and loss rates of phytoplankton from time-series observations of ${ }^{14}$-C-bicarbonate uptake
}

\author{
Richard J. Geider \\ Department of Plant Biology, University of Birmingham, PO Box 363, Birmingham B15 2TT, United Kingdom
}

\begin{abstract}
Particulate organic ${ }^{14} \mathrm{C}$ accumulated linearly for periods of 10 to $12 \mathrm{~h}$ when natural assemblages of phytoplankton from the Celtic Sea were incubated with ${ }^{14} \mathrm{C}$-bicarbonate at a constant illumination of $145 \mathrm{\mu mol}$ photons $\mathrm{m}^{-2} \mathrm{~s}^{-1}$. Biomass-specific photosynthesis rates (P/B) estimated for the $>1.0 \mathrm{um}$ size fraction ranged from 0.05 to $0.11 \mathrm{~h}^{-1}\left(0.6\right.$ to $1.3 \mathrm{~d}^{-1}$ for a $12 \mathrm{~h}$ photoperiod) at a temperature of $11^{\circ} \mathrm{C}$. Linear particulate ${ }^{14} \mathrm{C}$ accumulation, and other independent measurements, suggest that the photosynthetically active phytoplankton biomass was not increasing during the incubations (i.e. the growth rate was negligible). A rapid turnover of phytoplankton carbon and/or accumulation of energy storage reserves are possible mechanisms which could account for the absence of growth when photosynthesis rates were high. There was no evidence for enhanced phytoplankton growth rates in samples diluted with filtered seawater, indicating that microzooplankton grazing did not greatly influence productivity estimates in these samples. Estimates of phytoplankton respiration rates from the dark loss of organic ${ }^{14} \mathrm{C}$ ranged from 20 to $80 \%$ of the rate of photosynthetic accumulation of ${ }^{14} \mathrm{C}$ in the light, and cannot fully account for the apparent discrepancy between photosynthesis and growth. This leaves the accumulation of non-photosynthetic biomass under the experimental culture conditions as a likely, but untested possibility. Indirect evidence is cited to support this hypothesis.
\end{abstract}

\section{INTRODUCTION}

The rate of particulate organic ${ }^{14} \mathrm{C}$ production is the most commonly measured index of primary production in the sea. Almost from its inception, however, the ${ }^{14} \mathrm{C}$ technique has been a source of controversy (Peterson 1980). Initially, the controversy surrounded the extent to which ${ }^{14} \mathrm{C}$ uptake measured gross or net phytoplankton photosynthesis. This question has been addressed both theoretically (Buckingham et al. 1975, Hobson et al. 1976, Marra et al. 1981, Dring \& Jewson 1982, Smith 1982) and experimentally (Eppley \& Sloan 1965, Ryther $\&$ Menzel 1965). In general, ${ }^{14} \mathrm{C}$-uptake by autotrophs measures something between net and gross primary production. What exactly is measured depends on the relationship between photosynthesis and respiration rates, the degree of heterogeneity of intracellular carbon pools, and the duration of the experiment. Net and gross primary productivity are virtually indistiguishable in rapidly growing phytoplankton when the respiration rate is a very small fraction of the photosynthesis rate (Peterson 1980, Smith 1982). They will become increasing dissimilar in magnitude as the ratio of respi- ration to photosynthesis increases (Dring \& Jewson 1982, Smith 1982). Low photosynthesis:respiration ratios, however, are not sufficient to cause ${ }^{14} \mathrm{C}$-uptake to overestimate net production unless the substrates for respiration are separated from the early products of photosynthesis (Smith \& Platt 1984). If respiration is from a small pool of metabolic intermediates that are labelled rapidly, then the ${ }^{14} \mathrm{C}$-uptake rate will be close to the rate of net primary production (Smith \& Platt 1984, Smith \& Geider 1985). However, if the substrates for respiration are largely derived from unlabelled (storage) products, then the ${ }^{14} \mathrm{C}$-uptake rate will be close to gross primary productivity until these pools become significantly labelled (Bidwell 1977). Under stressed conditions associated with changes in metabolic state or community population structure, respiration may be stimulated and derived largely from unlabelled biomass (Peterson 1978, Mague et al. 1980).

The interpretation of ${ }^{14} \mathrm{C}$-uptake rates in the plankton is considerably complicated by ecological interactions between components of the microbial community (Peterson 1980, Jackson 1983, Smith et al. 1984). It has been suggested that ${ }^{14} \mathrm{C}$-uptake will severely underes- 
timate net primary productivity when phytoplankton are growing rapidly, but net population increase is kept in check by high loss rates to grazers (Sheldon \& Sutcliffe 1978). Theoretical exercises suggest that the magnitude of the discrepancy between net primary production and ${ }^{14} \mathrm{C}$-uptake will rarely exceed a factor of 2 over 12 to $24 \mathrm{~h}$ incubations, although the organic ${ }^{14} \mathrm{C}$ will be distributed amongst both autotrophs and heterotrophs (Jackson 1983, Smith et al. 1984). ${ }^{14} \mathrm{C}$ uptake will underestimate net primary productivity to the extent that organic ${ }^{14} \mathrm{C}$ is remineralized by heterotrophs.

Recent, direct comparisons indicate that ${ }^{14} \mathrm{C}$-uptake and other techniques yield roughly comparable fluxes of carbon through microplankton communities (Williams et al. 1979, Williams et al. 1983, Davies \& Williams 1984, Laws et al. 1984). Exact agreement is not to be expected because different techniques measure different processes. In fact, the differences between independent measurements can be exploited to gain insight into microplankton community dynamics (Smith et al. 1984).

The importance of microbial interactions in marine food webs has necessitated a re-evaluation of the framework for interpreting primary production measurements (Peterson 1980, Jackson 1983, Smith et al. 1984). Planktonic microbial food webs often have complex structures with autotrophs and heterotrophs sharing a common size range of about 6 orders of magnitude in cell volume for organisms with typical dimensions of 0.5 to $100 \mu \mathrm{m}$ (Sieburth et al. 1978, Williams 1981, Azam et al. 1983). Much of the metabolic activity, however, is concentrated in the smallest size classes which are most difficult to manipulate experimentally. Picoplanktonic photoautotrophs account for 20 to $80 \%$ of phytoplankton biomass and primary production in the sea (Joint \& Pomroy 1983, Li et al. 1983, Platt et al. 1983, Takahashi \& Bienfang 1983, Douglas 1984, Joint et al. 1986). In coastal waters, phytoplankton which pass a 5 to $10 \mu \mathrm{m}$ pore sieve account for about $50 \%$ of biomass and photosynthesis (Furnas 1983, Joint \& Pomroy 1983). Heterotrophic activity is also concentrated in the pico-and nanoplankton (Williams 1981). Up to half of phytoplankton photosynthate may be excreted as labile dissolved organic carbon which is kept at a low concentration in seawater by active bacterial metabolism (Lancelot 1979, Keller et al. 1982, Jensen 1983). Ciliates have been implicated as major consumers of nanoplankton (Burkill 1982, Verity 1986) and picoplankton (Sherr \& Sherr 1987), and heterotrophic flagellates are considered to be major consumers of both heterotrophic and autotrophic picoplankton (Johnson et al. 1982, Sieburth \& Davis 1982, Landry et al. 1984). Complicating the interpretation of productivity experiments is the degree to which microbial interactions affect phytoplankton growth and photosynthesis. The effect of microzooplankton grazing on ${ }^{14} \mathrm{C}$ uptake and biomass production has been treated theoretically (Jackson 1983, Smith et al. 1984). The purpose of this paper is to explore the potential of coupling time-series measurements of organic ${ }^{14} \mathrm{C}$ production with the dilution approach of Landry \& Hassett (1982) in order to gain insights into microplankton community metabolism.

\section{METHODS}

Experiments were conducted on the 17 May to 9 June, 1986, cruise of the RRS 'Charles Darwin' to Station CSII $\left(50^{\circ} \mathrm{N}, 7^{\circ} \mathrm{W}\right)$ in the Celtic Sea as part of a multi-investigator study of food chain dynamics within the picoplankton and nanoplankton. Samples were collected in 301 water bottles at various depths between 10 and $25 \mathrm{~m}$. This paper describes the results of timeseries ${ }^{14} \mathrm{C}$-bicarbonate uptake experiments (Table 1) which were designed to measure phytoplankton growth under controlled environmental conditions. Cumulative organic ${ }^{14} \mathrm{C}$-uptake time series (5 experiments) and/or discrete, short-term organic ${ }^{14} \mathrm{C}$-uptake rate time-series ( 4 experiments) were measured in both diluted and undiluted seawater (Landry \& Hassett 1982) to assess the influence of microzooplankton grazing on phytoplankton productivity. In addition, samples were examined microscopically to determine nanoplankton numbers and biomass.

Seawater (10 to 20 l) was screened through either 125 um (24 and 25 May experiments) or $30 \mu \mathrm{m}$ mesh Nitex screens (all other dates). Particle-free seawater was prepared by gentle vacuum filtration $(<20 \mathrm{kPa})$ through Millipore 0.45 um pore size cellulose acetate filters that had been previously rinsed with a small volume $(100$ to $200 \mathrm{ml})$ of seawater. Samples for incubation were prepared by mixing appropriate volumes of screened and filtered seawater to a final volume of about $1 \mathrm{l}$ in experimental containers (Duran borosilicate glass bottles). Containers were rinsed with $10 \%$ hydrochloric acid and filtered seawater between experiments. The inorganic nutrient concentration was increased by $10 \mu M \mathrm{NH}_{4} \mathrm{Cl}$ and $1 \mu \mathrm{M} \mathrm{KH}_{2} \mathrm{PO}_{4}$ for all experiments. Experimental vessels containing nutrient-enriched seawater samples were allowed to acclimate in the light for 30 to 60 min prior to addition of ${ }^{14} \mathrm{C}$-bicarbonate and initiation of time-series measurements. Illumination was from below with fluorescent light at a photon flux density of $0.9 \times 10^{16}$ quanta $\mathrm{cm}^{-2} \mathrm{~s}^{-1}=145$ mol photons $\mathrm{m}^{-2} \mathrm{~s}^{-1}$ as measured with a Biospherical Instruments $4 \pi$ quantum sensor $(\lambda=400$ to $700 \mathrm{~nm}$ ). In some experiments the subsequent loss of organic ${ }^{14} \mathrm{C}$ activity was measured during incubations 
Table 1 List of ${ }^{14} \mathrm{C}$-bicarbonate uptake experiments conducted during the peak and early decline of the Celtic Sea spring bloom, 1986

\begin{tabular}{|llll|}
\hline Date & Depth & \multicolumn{1}{c|}{$\begin{array}{c}\text { Type of }{ }^{14} \mathrm{C} \\
\text { uptake experiment }\end{array}$} & \multicolumn{1}{c|}{ Dilutions } \\
\hline 24 May & $20 \mathrm{~m}$ & Discrete & $100 \%, 50 \%, 25 \%$ \\
$25 \mathrm{May}$ & $20 \mathrm{~m}$ & Discrete \& cumulative & $100 \%$ \\
$26 \mathrm{May}$ & $20 \mathrm{~m}$ & Discrete \& cumulative & $100 \%, 25 \%$ \\
29 May & $10 \mathrm{~m}$ & Discrete & $100 \%, 25 \%$ \\
30 May & $10 \mathrm{~m}$ & Cumulative & $100 \%, 25 \%, 10 \%$ \\
4 June & $25 \mathrm{~m}$ & Cumulative & $100 \%, 30 \%, 10 \%$ \\
5 June & $10 \mathrm{~m}$ & Cumulative & $100 \%$ \\
\hline
\end{tabular}

in darkness. Temperature was maintained at $10.5 \pm$ $0.5^{\circ} \mathrm{C}$.

For time-series observations of particulate organic ${ }^{14} \mathrm{C}$ accumulation, $1 \mathrm{ml}$ of stock $\mathrm{Na}\left[{ }^{14} \mathrm{C}\right.$-bicarbonate (Amersham International) was added to $1 \mathrm{l}$ of sample giving a final activity of 2 to $6 \times 10^{7} \mathrm{~Bq} \mathrm{ml}{ }^{-1}$. Subsamples were immediately taken for time-zero organic ${ }^{14} \mathrm{C}$ activity and total activity. For total activity $0.5 \mathrm{ml}$ of sample was added to a scintillation vial containing $0.1 \mathrm{ml}$ of $1 \mathrm{M} \mathrm{NaOH}$ and $4 \mathrm{ml}$ of Ready-Solv EP scintillation cocktail (Beckman). Particulate organic ${ }^{14} \mathrm{C}$ activity was measured on $10.0 \mathrm{ml}$ aliquots filtered onto Whatman GF/F glass fiber filters under low pressure differentials. The filters were fumed with concentrated $\mathrm{HCl}$ for 15 min prior to transfer to a scintillation vial and addition of $4.5 \mathrm{ml}$ of Ready-Solv EP. For the total organic ${ }^{14} \mathrm{C}$ activity measurement a $10.0 \mathrm{ml}$ aliquot was added to a glass scintillation vial containing $1 \mathrm{ml}$ of $1 \mathrm{~N}$ $\mathrm{HCl}$, sealed and stored for further processing ashore. Total organic activity was measured in $1.0 \mathrm{ml}$ subsamples transfered to glass scintillation vials. Inorganic ${ }^{14} \mathrm{C}$ was allowed to outgas for $24 \mathrm{~h}$ before addition of $9 \mathrm{ml}$ of Ready-Solv EP. Time-zero organic ${ }^{14} \mathrm{C}$ activities obtained using this technique were only slightly higher than background levels and negligible in comparison with measured production. Dissolved organic ${ }^{14} \mathrm{C}$ was measured in filtrates from Whatman GF/F glass fiber filters in a manner strictly analogous to that described above for total organic ${ }^{14} \mathrm{C}$. Scintillation counting was done on a United Technologies Packard Tricarb 4530 scintillation counter. Quench correction was by the external standards method.

In some experiments a different protocol was followed. For these ${ }^{14} \mathrm{C}$-bicarbonate was not added to the experimental vessel; instead discrete, short-term (about $1 \mathrm{~h}$ ) ${ }^{14} \mathrm{C}$-bicarbonate uptake was measured in subsamples withdrawn at various times as the incubation proceeded. The protocol was as follows. A $10.0 \mathrm{ml}$ subsample was removed from the incubation vessel and placed into a $30 \mathrm{ml}$ capacity polypropylene tube
(Sterilin). Then $50 \mu \mathrm{l}$ of ${ }^{14} \mathrm{C}$-bicarbonate solution was added to the sample, giving a final activity of 2 to $6 \times$ $10^{7} \mathrm{~Bq} \mathrm{~m}^{-1}$. The sample was placed in a test-tube rack adjacent to the incubation vessel and allowed to incubate for $1 \mathrm{~h}$. The incubation was terminated by filtration through a Whatmann GF/F filter, after which time the filter was treated as described above for particulate organic ${ }^{14} \mathrm{C}$ activity. Total activity was determined on $50 \mu \mathrm{l}$ of stock ${ }^{14} \mathrm{C}$-bicarbonate solution which was added to a scintillation vial containing $0.5 \mathrm{ml}$ of $0.2 \mathrm{M}$ $\mathrm{NaOH}$ and $4 \mathrm{ml}$ of Ready-Solv EP. Phytoplankton were exposed to a slightly lower photon flux density in these discrete incubations because of shading by the test tube rack. It was found that the ${ }^{14} \mathrm{C}$ uptake rates in the Sterilin tubes were only $85 \%$ of those found in the Duran bottles.

One set of samples from each particulate ${ }^{14} \mathrm{C}$ accumulation time series was used to determine sizefractionated organic ${ }^{14} \mathrm{C}$ activities. Separate $10.0 \mathrm{ml}$ samples were filtered through $1.0,3.0$ and $5.0 \mu \mathrm{m}$ pore size Nuclepore filters to determine activity in $>1.0$, $>3.0$, and $>5.0 \mu \mathrm{m}$ size fractions. Samples were filtered to dryness under low pressure differentials $k<10$ $\mathrm{kPa}$ ) and the sample dehydrated over silica gel before addition of Ready-Solv EP scintillation cocktail. Samples for total and particulate organic ${ }^{14} \mathrm{C}$ activity were collected as described previously. In addition, samples for dissolved organic ${ }^{14} \mathrm{C}$ activity were taken from the filtrate of a GF/F filtration. Samples for size fractionation measurements were taken after incubation with added tracer for 10 to $11 \mathrm{~h}$ (25,26 and 30 May) or about $24 \mathrm{~h}$ ( 4 and 5 June).

Subsamples were collected from 125 or $30 \mu \mathrm{m}$ Nitex screened seawater for chlorophyll a determinations and nanoplankton cell counts. For chlorophyll a determinations $100 \mathrm{ml}$ of sample was collected on a Whatman GF/F filter. The filter was placed in $10.0 \mathrm{ml}$ of $90 \%$ acetone and chlorophyll allowed to extract for at least $24 \mathrm{~h}$ at $-20^{\circ} \mathrm{C}$ prior to determination of chlorophyll a concentration by a fluorescence technique (Holm-Hansen et al. 1965). Cell counts of nanoplankton were made on Lugol's iodine-fixed samples in glycerine jelly preparations. A $50 \mathrm{ml}$ sample was cleared of iodine by addition of a few drops of dilute sodium thiosulphate (Joint \& Pomroy 1983) followed by addition of glutaraldehyde to a final concentration of $1.0 \%$. The sample was then collected on a $1.0 \mu \mathrm{m}$ pore Nuclepore filter backed by a $0.45 \mu \mathrm{m}$ pore Millipore filter. The concentrated sample was transfered from the Nuclepore filter into a glycerine jelly preparation (Geider 1987a). Glycerine jelly preparations were examined with phase contrast microscopy at magnifications of $250 \times, 400 \times$ and $1000 \times$ using a Leitz Orthoplan microscope. Cells with equivalent spherical diameters (ESD) of less than $4.25 \mu \mathrm{m}$ were sized and counted from measurements on 
projected slides. Cryptomonads, small dinoflagellates, and other cells with ESDs greater than $4.0 \mu \mathrm{m}$ were sized and counted directly at $400 \times$. Ciliates were counted at a magnification of $250 \times$.

\section{RESULTS}

Particulate organic ${ }^{14} \mathrm{C}$ accumulated linearly over periods of 10 to $12 \mathrm{~h}$ (Fig. 1 ) in all experiments and at all dilutions. Production rates calculated from linear regression analysis ranged from 1.4 to $5.1 \mathrm{mg} \mathrm{C} \mathrm{m}^{-3} \mathrm{~h}^{-1}$ in undiluted seawater (Table 2). Linearity is one criterion used to indicate that serious methodological artifacts such as cell mortality or nutrient exhaustion have not affected production estimates (Goldman et al. 1981), although this inference is not guaranteed ( $\mathrm{Li} \&$ Goldman 1981). In fact, the photosynthesis rate (units of $\mathrm{mg} \mathrm{C} \mathrm{m}^{-3} \mathrm{~h}^{-1}$ ) can be expected to increase with time
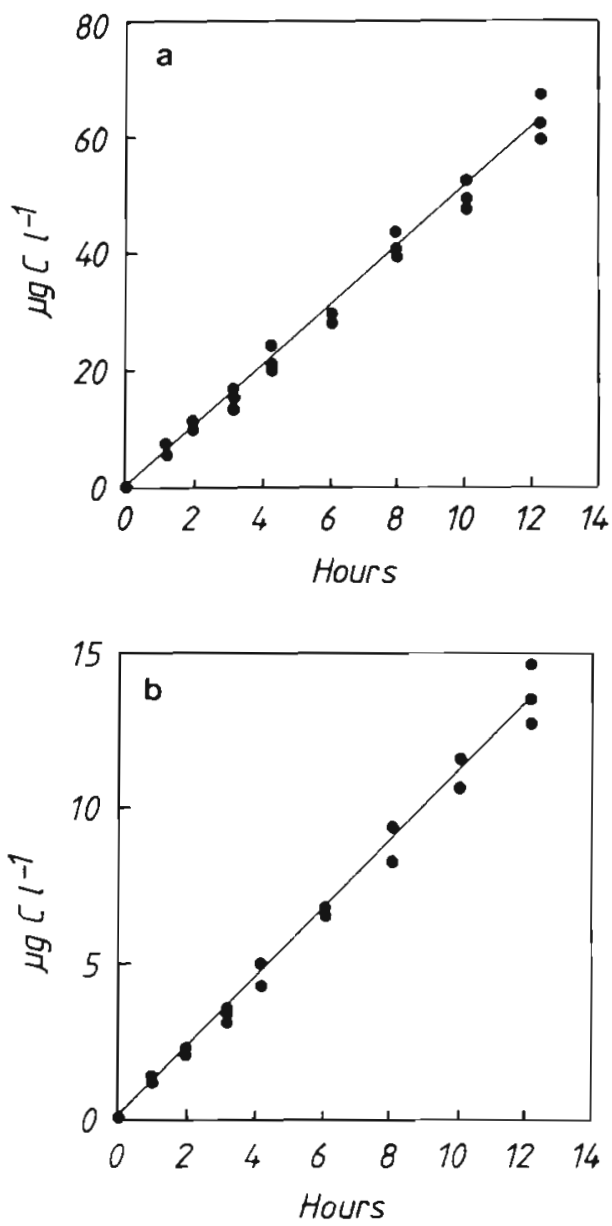

Fig. 1. Particulate organic ${ }^{14} \mathrm{C}$ accumulation during continuous, constant illumination at a photon flux density of $140 \mu \mathrm{mol}$ $\mathrm{m}^{-2} \mathrm{~s}^{-1}$ during the 26 May experiment. (a) Uptake in the undiluted sample; (b) uptake in a sample diluted to $25 \%$ of ambient concentration with particle-free seawater in a growing population, or decrease in a declining population, and these changes should be reflected in time-series observations of particulate ${ }^{14} \mathrm{C}$ accumulation (Eppley 1968, Jackson 1983).

Linear particulate ${ }^{14} \mathrm{C}$ accumulation is expected in populations that are growing slowly either because of a physiological limitation on phytoplankton growth or because grazing by microzooplankton limits the increase in population size of a rapidly photosynthesizing population. If microzooplankton grazing limits the net population increase of phytoplankton, then dilution with particle-free seawater (Landry \& Hassett 1982) should enhance the rate of ${ }^{14} \mathrm{C}$ accumulation over an extended time period (Jackson 1983). This is expected despite the complexities which might exist in phytoplankton ${ }^{14} \mathrm{C}$ metabolism (Smith 1982, Smitz \& Platt 1984), or diel rhythms in biomass-specific photosynthesis rates (McCaull \& Platt 1977, Harding et al. 1982 Kana et al. 1985, Putt \& Prézelin 1985).
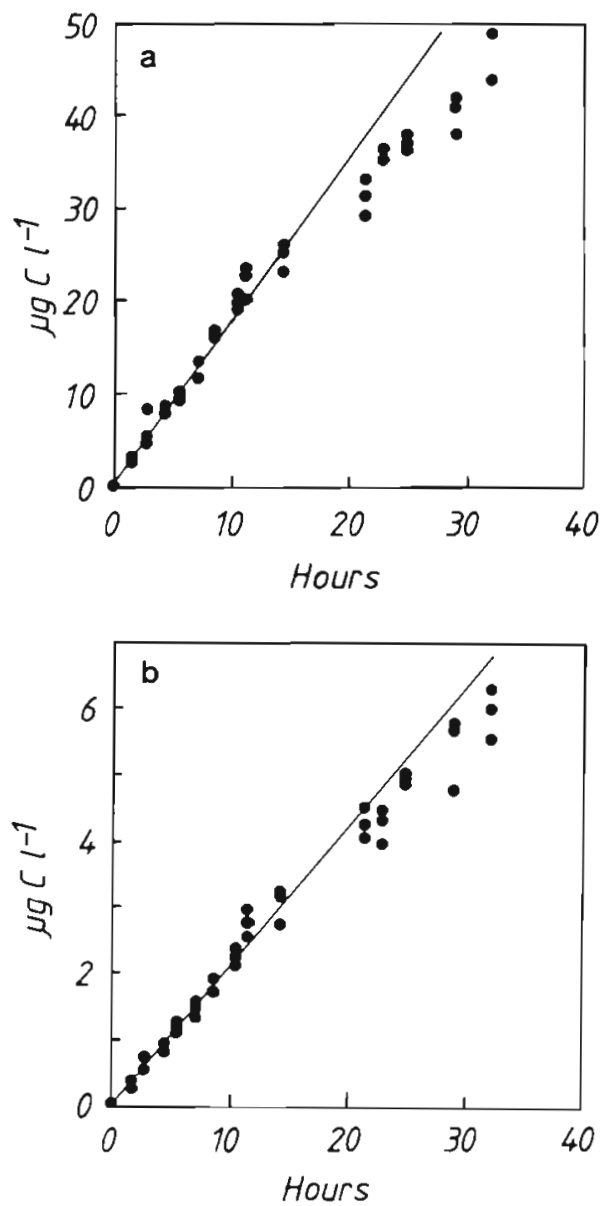

Fig. 2. Particulate organic ${ }^{14} \mathrm{C}$ accumulation during continuous illumination at a photon flux density of $140 \mu \mathrm{mol} \mathrm{m} \mathrm{m}^{-2} \mathrm{~s}^{-1}$ during the 30 May experiment. (a) Uptake in an undiluted sample; (b) uptake in a sample diluted to about $10 \%$ of ambient concentrations with particle-free seawater 
Over typical time periods for measuring primary production (i. e. about $12 \mathrm{~h}$ ), particulate ${ }^{14} \mathrm{C}$ accumulation was linear in both undiluted samples and samples diluted with filtered seawater to between 10 and $30 \%$ of ambient particulate concentrations. Thus, dilution had no effect on uptake kinetics other than that which was attributable to a difference of initial phytoplankton biomass (Table 2). Rates of particulate ${ }^{14} \mathrm{C}$ accumulation in diluted samples were sometimes greater than would be expected on the basis of the extent of dilution (i. e. at $10 \%$ dilution on 30 May and 4 June). In these cases, however, enhanced rates were evident from the start of the incubation and thus do not provide evidence for net growth in diluted samples. Instead, they may indicate an error in dilution, or stimulation of the biomass-specific rate of photosynthesis as a consequence of sample handling. The observation of linear particulate ${ }^{14} \mathrm{C}$ accumulation in both diluted and undiluted samples suggests that neither nutrient exhaustion nor microzooplankton grazing activity seriously affected particulate ${ }^{14} \mathrm{C}$ accumulation in these experiments. It is possible that the phytoplankton growth rates were low even in the absence of grazing and differences due to dilution could not be resolved. We return to this point below.

The declining slope of particulate ${ }^{14} \mathrm{C}$ accumulation under continuous illumination for periods greater than $15 \mathrm{~h}$ (Fig. 2) may indicate the onset of physiological stress in a community exposed to an unnaturally long light period. Alternatively, it may indicate increasing mineralization of organic ${ }^{14} \mathrm{C}$ as the population becomes uniformly labelled with tracer. For example,
Li \& Harrison (1982) demonstrated that downward curvature in a plot of particulate ${ }^{14} \mathrm{C}$ accumulation was due to increasing contribution of labelled substrate to respiration during a $32 \mathrm{~h}$ incubation.

Time-series of particulate ${ }^{14} \mathrm{C}$ accumulation that are $<12 \mathrm{~h}$ in duration may not provide the information necessary to examine the influence of microbial grazers on phytoplankton populations if the biomass-specific photosynthesis rates are low. Long time-series (>12 h), however, may be criticized because of physiological stresses associated with prolonged confinement and incubation under continuous illumination. Instead, it may be better to use the light-saturated ${ }^{14} \mathrm{C}$ incorporation rate over a discrete, short period (i. e. 1 to $2 \mathrm{~h}$ ) as an indicator of changes in biomass. Strictly, changes in uptake rates are used to infer changes in 'metabolically active' biomass. A similar technique has been used successfully in studies of bacterial growth rates in nature (Kirchman et al. 1982, Li 1984).

In 4 experiments ${ }^{14} \mathrm{C}$ uptake was measured using discrete $1 \mathrm{~h}$ incubations, but incubations were initiated at several times during 10 to $12 \mathrm{~h}$ of constant illumination. In one experiment (26 May), the ${ }^{14} \mathrm{C}$ uptake rate was measured after an additional $13 \mathrm{~h}$ in darkness. In 3 cases ${ }^{14} \mathrm{C}$ uptake rates are best characterized by a mean which did not change with time (Fig. 3). The constant ${ }^{14} \mathrm{C}$ uptake rates observed in the series of discrete ${ }^{14} \mathrm{C}$-uptake experiments suggests that phytoplankton biomass was not increasing during the incubations. This interpretation is consistent with the linear particulate ${ }^{14} \mathrm{C}$ accumulation described earlier. Also consistent with this interpretation are observations

Table 2. Rate of total or particulate organic ${ }^{14} \mathrm{C}$ accumulation calculated using linear regression analysis. The standard deviation of the slope (SD) is given in parentheses; $n$ : number of observations. A comparison was made between ${ }^{14} \mathrm{C}$ uptake in samples to which nutrients had been added (indicated $100 \%+$ ) or omitted (indicated $100 \%-$ ) in the 5 June experiment. Nutrients were added in all other experiments

\begin{tabular}{|c|c|c|c|c|c|c|}
\hline \multirow{2}{*}{\multicolumn{2}{|c|}{ Date and dilution }} & \multicolumn{4}{|c|}{ Productivity ( $\mathrm{mg} \mathrm{C} \mathrm{m}^{-3} \mathrm{~h}^{-1}$ ) } & \multirow{3}{*}{$\frac{\begin{array}{c}\text { Duration of } \\
\text { experiment }(\mathrm{h})\end{array}}{11.0}$} \\
\hline & & \multicolumn{2}{|c|}{ Slope (SD) } & \multirow{2}{*}{$n$} & \multirow{2}{*}{$\frac{r^{2}}{0.980}$} & \\
\hline 25 May & $100 \%$ (particulate) & 5.06 & $(0.15)$ & & & \\
\hline 25 May & $100 \%$ (total) & 5.08 & $(0.05)$ & 24 & 0.998 & 11.0 \\
\hline \multirow[t]{4}{*}{26 May } & $100 \%$ (particulate) & 4.85 & $(0.10)$ & 27 & 0.990 & 12.3 \\
\hline & $100 \%$ (total) & 5.08 & $(0.10)$ & 27 & 0.991 & 12.3 \\
\hline & $25 \%$ (particulate) & 1.15 & $(0.06)$ & 24 & 0.947 & 12.3 \\
\hline & $25 \%$ (total) & 1.11 & $(0.02)$ & 27 & 0.992 & 12.3 \\
\hline \multirow[t]{3}{*}{30 May } & $100 \%$ (particulate) & 1.79 & $(0.05)$ & 29 & 0.978 & 14.4 \\
\hline & $25 \%$ (particulate) & 0.526 & $(0.016)$ & 30 & 0.973 & 14.4 \\
\hline & $10 \%$ (particulate) & 0.218 & $(0.006)$ & 30 & 0.977 & 14.4 \\
\hline \multirow[t]{5}{*}{4 June } & $100 \%$ (particulate) & 2.66 & $(0.08)$ & 21 & 0.985 & 12.9 \\
\hline & $100 \%$ (total) & 2.55 & $(0.04)$ & 21 & 0.995 & 12.9 \\
\hline & $30 \%$ (particulate) & 0.850 & $(0.022)$ & 21 & 0.987 & 12.9 \\
\hline & $30 \%($ total $)$ & 0.776 & $(0.014)$ & 21 & 0.993 & 12.9 \\
\hline & $10 \%$ (particulate) & 0.393 & $(0.026)$ & 21 & 0.921 & 12.9 \\
\hline \multirow[t]{2}{*}{5 June } & $100 \%+$ (particulate) & 1.41 & $(0.04)$ & 19 & 0.990 & 12.1 \\
\hline & $100 \%-($ particulate $)$ & 1.44 & $(0.03)$ & 21 & 0.990 & 12.1 \\
\hline
\end{tabular}


from 4 experiments in which chlorophyll a concentration in undiluted samples did not change between the start and end of the period of illumination (i. e. 25 May initial chlorophyll a concentration $=2.47 \mu \mathrm{g}^{-1}$, final concentration $=2.52 \mu \mathrm{g} \mathrm{l}^{-1} ; 26$ May initial concentration $=1.86 \mu \mathrm{g} \mathrm{l}^{-1}$, final concentration $=1.88 \mu \mathrm{g} \mathrm{l}^{-1}$ 30 May initial concentration $=1.02 \mathrm{ug} \mathrm{l}^{-1}$, final concentration $=1.13 \mu \mathrm{g} \mathrm{l}^{-1}$ i 3 June initial concentration $=1.04$ $\mu g \mathrm{l}^{-1}$, final concentration $=1.05 \mu \mathrm{g} \mathrm{l}^{-1}$ ). Samples for changes in chlorophyll concentration and/or short-term ${ }^{14} \mathrm{C}$ uptake are not always available for direct comparison with particulate ${ }^{14} \mathrm{C}$ accumulation time series. This is a particularly unfortunate for the 4 and 5 June experiments in which samples for both initial and final chlorophyll a determinations were lost. In absence of direct comparisons, it is assumed that observations made on different days are representative of a similar phytoplankton community in a physiological condition.

Only in the first experiment (24 May) did the shortterm ${ }^{14} \mathrm{C}$ uptake rate increase with time (Fig. 3). The ratio of final to initial uptake rates averaged 1.7 times, independent of dilution, again suggesting that neither losses to grazers nor nutrient exhaustion were major determinants of phytoplankton production. Lugol'sfixed samples were available from both the start and the end of this incubation. Biomass as determined from cell counts (see below) increased by 1.5 times from 71 to $109 \mu \mathrm{g} \mathrm{C} \mathrm{I}^{-1}$ during the incubation. Given possible errors in cell counting and sizing, this increase in biomass compares favourably with the observed increase in ${ }^{14} \mathrm{C}$ uptake rate. The increase in biomass resulted from both an increase in numbers and a shift in the size distribution to larger cells.

Table 3 summarizes the observed size distribution of microorganisms retained by a $1.0 \mu \mathrm{m}$ pore sieve. This size range included an assemblage of microorganisms that was initially dominated by a diatom (Minidiscus trioculatus) and prymnesiophyte (Phaeocystis pouchetil) at the small end and by small unidentified dinoflagellates and cryptomonads in the larger sizes. Casual observations using epifluorescence microscopy at sea revealed that most of the nanoplankton as identified from DAPI fluorescence also showed chlorophyll or phycoerythrin autofluorescence. Previous investiga-
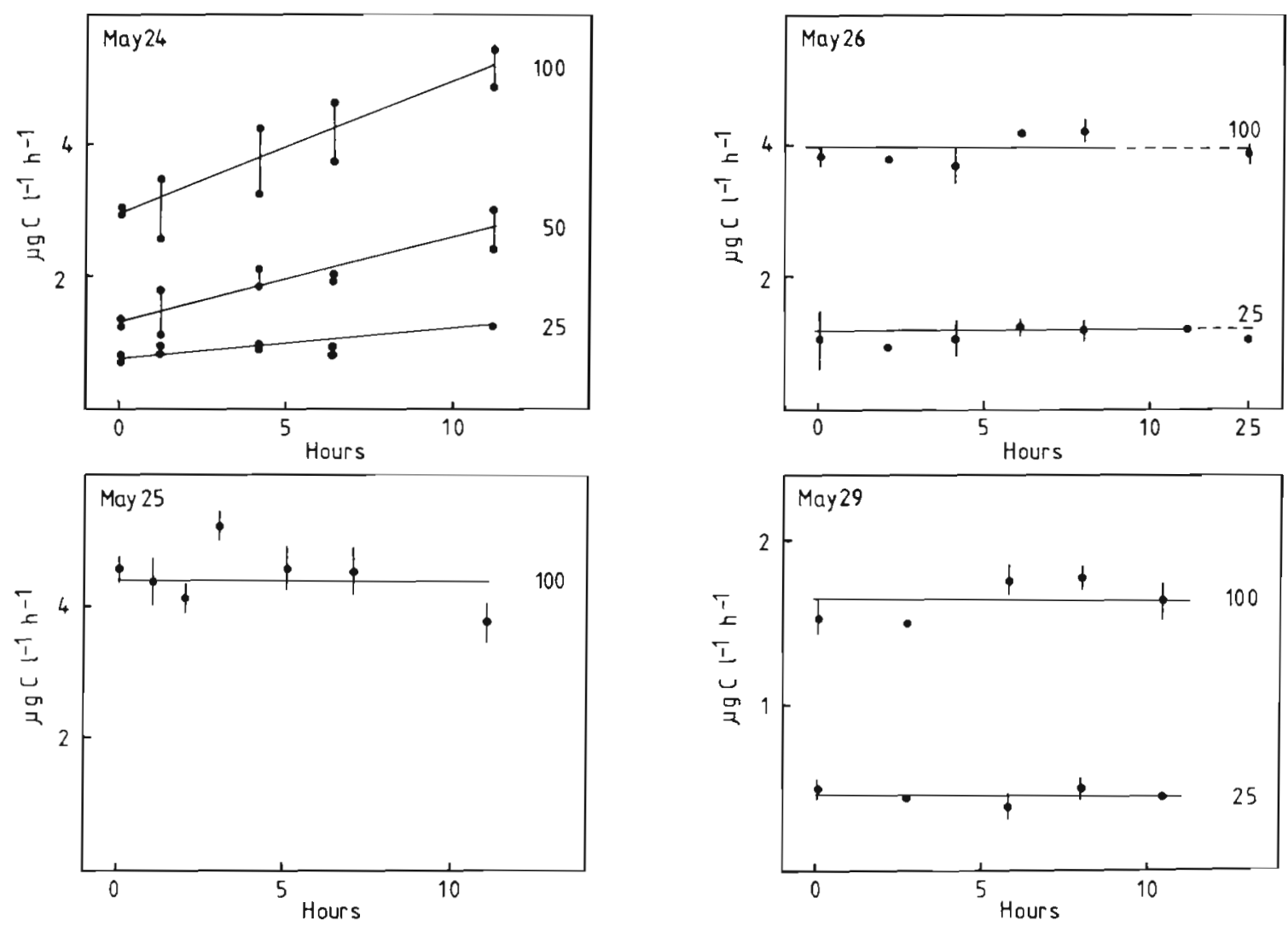

Fig. 3. Results of series observations of short-term ${ }^{14} \mathrm{C}$ uptake for $24,25,26$ and 29 May. Duplicate samples were incubated for each time point durng the 24 May experiment whereas triplicate samples were used in all other experiments. Each observation is illustrated for the $24 \mathrm{May}$ experiment with the duplicate samples joined by a vertical line. The mean \pm standard deviation is lllustrated for all other experiments. The trends (24 May) or means (all others) are indicated by the solid lines. Samples consisted of undiluted seawater and seawater diluted to 50 or $25 \%$ of ambient concentrations as indicated to the right of each line in the 
Table 3. Nanoplankton concentrations in Celtic Sea sample. ESD: equivalent spherical diameter in $\mu \mathrm{m}$

\begin{tabular}{|c|c|c|c|c|c|c|c|}
\hline \multirow[t]{2}{*}{ Cell size (ESD) } & \multicolumn{7}{|c|}{ Cell concentration $\left(10^{3}\right.$ cells $\left.\mathrm{ml}^{-1}\right)$} \\
\hline & 24 May & 25 May & $26 \mathrm{May}$ & 29 May & 30 May & 4 June & 5 June \\
\hline \multicolumn{8}{|c|}{ Unidentified unicells } \\
\hline 1.5 & 4.0 & 4.2 & 0.65 & 1.9 & 0.55 & 2.2 & nd \\
\hline 2.0 & 8.8 & 8.4 & 1.5 & 3.3 & 1.5 & 2.9 & 0.72 \\
\hline 2.5 & 4.7 & 6.3 & 1.4 & 2.7 & 1.3 & 1.7 & 0.60 \\
\hline 3.0 & 2.0 & 1.7 & 0.97 & 1.5 & 0.78 & 1.9 & 0.58 \\
\hline 3.5 & 1.3 & 1.4 & 0.39 & 0.86 & 0.55 & 0.26 & 0.31 \\
\hline 4.0 & 0.84 & 0.25 & 0.09 & 0.57 & 0.32 & 0.06 & 0.25 \\
\hline 5.0 & 0.42 & 0.33 & 0.23 & 0.35 & 0.18 & 0.090 & 0.22 \\
\hline 7.0 & 0.14 & 0.076 & 0.055 & 0.12 & 0.056 & 0.044 & 0.024 \\
\hline 9.0 & 0.045 & 0.007 & 0.018 & 0.029 & 0.026 & 0.002 & 0.005 \\
\hline 11.0 & 0.007 & $<0.007$ & 0.006 & 0.011 & 0.006 & $<0.002$ & $<0.002$ \\
\hline \multicolumn{8}{|l|}{ Cryptomonads } \\
\hline $3.0-7.9$ & 1.1 & 0.69 & 0.47 & 0.21 & 0.31 & 0.24 & 0.029 \\
\hline \multicolumn{8}{|c|}{ Small dinoflagellates } \\
\hline $4.0-10$ & 0.41 & 0.47 & 0.17 & $<0.003$ & $<0.001$ & $<0.002$ & $<0.002$ \\
\hline Ciliates & 0.006 & 0.005 & 0.004 & 0.003 & 0.004 & 0.001 & 0.003 \\
\hline \multicolumn{8}{|c|}{ Biomass $>1 \mu \mathrm{m}$ (exclusive ciliates) $\left(\mu \mathrm{g} \mathrm{C} \mathrm{l}^{-1}\right.$ ) } \\
\hline & 71 & 55 & 26 & 36 & 22 & 18 & 10 \\
\hline
\end{tabular}

tions have consistently demonstrated that about $90 \%$ of nanoplankters at this location possess chloroplasts (Joint \& Pipe 1984, Joint et al. 1986). The observations indicate a maximum of numbers in the 2.0 and $2.5 \mu \mathrm{m}$ equivalent spherical diameter (ESD) size classes. The decrease in numbers in the smallest size class $(1.5 \mu \mathrm{m})$ may reflect the distribution in nature, or it may arise from a methodological artifact related to the porosity of sieves used to concentrate samples for enumeration. Microbes can often deform in response to shearing stresses, and may become aligned such that the longest dimension is parallel to the flow field, thus allowing cells with an ESD $>1.0 \mu \mathrm{m}$ to pass through a $1.0 \mu \mathrm{m}$ sieve.

The observed nanoplankton numbers were converted to biovolume by multiplying the concentration of cells within each size class by the volume corresponding to the midpoint ESD. A conversion factor of $0.2 \mathrm{pg} \mathrm{C}=1.0 \mathrm{\mu m}^{3}$ cell volume was used to obtain biomass from biovolume. This factor is consistent with that obtained for bacteria (Bratbak \& Dundas 1984), with that observed by Morgan \& Kalff (1979) for the cryptomonad Crytomonas erosa, with extrapolations based on Eppley et al. (1970) and Taguchi (1976) for diatoms with an ESD of 2.0 to $4.0 \mu \mathrm{m}$ and with extrapolations based on Strathmann (1967) and Eppley et al. (1970) for other microalgae with 2.0 to $10 \mu \mathrm{m}$ ESD. These values are not likely to seriously overestimate phytoplankton biomass retained by a $1.0 \mu \mathrm{m}$ pore size filter because microheterotrophs did not contribute significantly to nanoplankton numbers. They will under- estimate phytoplankton biomass to the extent that picoplankton are not retained on a $1.0 \mu \mathrm{m}$ sieve, or that delicate forms have been lost during preservation and storage.

Observations of size-fractionated ${ }^{14} \mathrm{C}$-uptake (Table 4)

Table 4. Size fractionation of organic ${ }^{14} \mathrm{C}$ production in undiluted seawater samples. Independent samples were collected on Whatmann GF/F, and 1.0,3.0 and $5.0 \mathrm{\mu m}$ pore size Nuclepore filters. The percentage of total organic ${ }^{14} \mathrm{C}$ in each size interval was obtained by difference. The GF/F filter was assumed to have a nominal pore size of $0.5 \mu \mathrm{m}$. Dissolved organic ${ }^{14} \mathrm{C}$ (i.e. $<0.5 \mu \mathrm{m}$ ) was measured in separate samples collected on 25, 26 and 29 May, but was calculated by difference between total organic ${ }^{14} \mathrm{C}$ production and that measured in the GF/F filter of 4 and 5 June

\begin{tabular}{|lrcccc|}
\hline $\begin{array}{l}\text { Date and } \\
\text { duration }\end{array}$ & \multicolumn{6}{c|}{$\begin{array}{c}\text { Percent of total }{ }^{14} \mathrm{C} \text { uptake in size fractions } \\
\text { Nominal size range }(\mu \mathrm{m})\end{array}$} \\
& $<0.5$ & $0.5-1.0$ & $1.0-3.0$ & $3.0-5.0$ & $>5.0$ \\
\hline 25 May, 11 h & 3.7 & 30 & 19 & 36 & 11 \\
26 May, 10 h & 3.9 & 32 & 30 & 23 & 11 \\
30 May, 11 h & 8.3 & 31 & 25 & 21 & 14 \\
4 June, 23 h & $<5.0$ & 37 & 35 & 18 & 10 \\
5 June, 24 h & $<5.0$ & 35 & 32 & 18 & 13 \\
$\begin{array}{l}\text { (-nutrients) } \\
\text { 5 June, 24 h }\end{array}$ & & & & & \\
(+nutrients) & $<4.0$ & 39 & 30 & 17 & 14 \\
$\begin{array}{l}\text { Mean } \\
\text { Standard }\end{array}$ & $<5.0$ & 34.0 & 28.5 & 22.2 & 12.1 \\
deviation & - & 3.6 & 5.7 & 7.1 & 1.7 \\
\hline
\end{tabular}


indicate that, on average, $35 \%$ of particulate organic ${ }^{14} \mathrm{C}$ activity passed through a $1.0 \mu \mathrm{m}$ sieve. To calculate biomass-specific photosynthesis rates with units of inverse time the observed particulate ${ }^{14} \mathrm{C}$ accumulation rate (Table 2) was multiplied by 0.65 and the resulting value inferred for $>1.0 \mu \mathrm{m}{ }^{14} \mathrm{C}$ production was divided by the $>1.0 \mu \mathrm{m}$ biomass. Photosynthesis rates (Table 5) calculated in this manner ranged from 0.05 to $0.11 \mathrm{~h}^{-1}$. These rates would imply biomass increases of 1.8 to 3.7 times over a $12 \mathrm{~h}$ photoperiod if growth were exponential. They contrast with the suggestion that phytoplankton biomass was largely unchanged in 10 to $14 \mathrm{~h}$ incubations based on the linearity of particulate ${ }^{14} \mathrm{C}$ accumulation, discrete ${ }^{14} \mathrm{C}$-uptake rates, and measurements of chlorophyll a concentration. These calculated photosynthesis rates are based on the observed linear accumulation of organic ${ }^{14} \mathrm{C}$ and inferred constant biomass:

$$
p=(1 / B)(\delta \beta / \delta t)
$$

where $p=$ photosynthesis rate $\left(\mathrm{h}^{-1}\right) ; B=$ phytoplankton biomass $\left(\mu \mathrm{g} \mathrm{Cl}^{-1}\right) ; \delta \beta$ is the organic ${ }^{14} \mathrm{C}$ production $(\mu \mathrm{g}$ $\mathrm{C}^{-1}$ ) observed in time interval $\delta t(\mathrm{~h})$. These photosynthesis rates appear to be high for mixed assemblages growing at a temperature of $11^{\circ} \mathrm{C}$. For example, a photosynthesis rate of $0.11 \mathrm{~h}^{-1}$ is 2.5 times greater than the maximum growth rate of microalgae at this temperature (Eppley 1972). The photosynthesis rates observed during the Celtic Sea spring bloom (Table 5) are similar to those measured for summer nanoplankton assemblages from Narragansett Bay where Furnas (1982) obtained a mean biomass-specific photosynthesis rate of $0.7 \mathrm{~d}^{-1}=0.06 \mathrm{~h}^{-1}$, assuming a $12 \mathrm{~h}$ photoperiod, at higher temperatures which ranged from 16 to $21^{\circ} \mathrm{C}$.

If phytoplankton biomass has been underestimated, then the calculated photosynthesis rates based on particulate ${ }^{14} \mathrm{C}$ accumulation will be in error. A comparison of measured biomass and chlorophyll concentrations, however, suggests that this is not the case. Values for

Table 5. Estimated values of net growth rate $(\mu)$, respiration rate $(r)$ and gross photosynthesis rate $(p=\mu+r)$ obtained from non-linear least squares fit of Eq. (10) to particulate organic ${ }^{14} \mathrm{C}$ accumulation time-series. Estimates were obtained only for undiluted samples

\begin{tabular}{|lllll|}
\hline Date & $\begin{array}{c}\mu \\
\left(\mathrm{h}^{-1}\right)\end{array}$ & $\begin{array}{c}r \\
\left(\mathrm{~h}^{-1}\right)\end{array}$ & $\begin{array}{c}p \\
\left(\mathrm{~h}^{-1}\right)\end{array}$ & $\begin{array}{c}\mathrm{P} / B \\
\left(\mathrm{~h}^{-1}\right)\end{array}$ \\
\hline $25 \mathrm{May}$ & 0.011 & 0.069 & 0.080 & 0.055 \\
$26 \mathrm{May}$ & 0.050 & 0.090 & 0.140 & 0.11 \\
30 May & 0.014 & 0.050 & 0.064 & 0.049 \\
4 June & 0.030 & 0.10 & 0.13 & 0.089 \\
5 June (+nutrients) & 0.034 & 0.087 & 0.12 & 0.085 \\
5 June (-nutrients) & 0.032 & 0.077 & 0.11 & 0.086 \\
\hline
\end{tabular}

the carbon:chlorophyll a ratio $(\mathrm{C}: \mathrm{chl}$ a) for the $>1.0 \mu \mathrm{m}$ size fraction were derived from the nanoplankton counts and observed total particulate chlorophyll a concentration in a manner analogous to that used to obtain biomass-specific photosynthesis rates. The observed total particulate chlorophyll a concentration was multiplied by 0.65 to account for the fraction of phytoplankton greater than $1.0 \mu \mathrm{m}$, and the carbon biomass determined by direct counts was divided by the inferred $>1.0 \mu \mathrm{m}$ chlorophyll a concentration to obtain C:chl a. Available values for $\mathrm{C}$ :chl a ranged from over $50 \mathrm{~g} \mathrm{C} \mathrm{g}^{-1} \mathrm{chl} a$ at $10 \mathrm{~m}$ (53 on 29 May; 55 on $30 \mathrm{May}$ ), to about $30 \mathrm{~g} \mathrm{C} \mathrm{g}^{-1} \mathrm{chl} a$ at 20 to $35 \mathrm{~m} \mathrm{(34} \mathrm{on} 25$ May; 24 on 26 May; 37 on 2 June; and 19 on 3 June). The values obtained from 20 to $35 \mathrm{~m}$ samples are indicative of nutrient-saturated and light-limited phytoplankton (Geider $1987 \mathrm{~b}$ ). The C:chl a ratios obtained from 2 samples collected at $10 \mathrm{~m}$ are somewhat greater possibly due to higher light levels encountered at the shallower depth (Geider 1987b).

Changes in biomass determined from both microscopy and discrete ${ }^{14} \mathrm{C}$ uptake rates can be compared for the 24 May experiment; the calculated photosynthesis rates were 0.033 and $0.044 \mathrm{~h}^{-1}$ respectively. After taking account of the fraction of organic ${ }^{14} \mathrm{C}$ retained by a $1.0 \mu \mathrm{m}$ filter (i. e. 0.65) and the difference in uptake rates between measurements made in Sterilin tubes and glass bottles (see 'Methods'), a photosynthesis rate of $0.032 \mathrm{~h}^{-1}$ is obtained by dividing the ${ }^{14} \mathrm{C}$ uptake rate by the initial biomass. Given the uncertainties involved in making these calculations, the 3 rates are in reasonable agreement. Thus, for the only experiment in which the biomass was definitely observed to change, the rate of ${ }^{14} \mathrm{C}$ uptake was comparable to the change in biomass. Unfortunately, particulate ${ }^{14} \mathrm{C}$ accumulation time-series were not measured on this occasion.

Much lower nanoplankton photosynthesis rates were obtained when calculations were based on an assumption of exponential growth during the incubation. For example, Eppley (1968) used the following equation to calculate biomass-specific photosynthesis rates.

$$
\left.p=(1 / \delta t) \ln \left[B_{0}+\delta \beta\right) /\left(B_{0}\right)\right]
$$

where $B_{0}=$ initial phytoplankton biomass $\left(\mu \mathrm{C} \mathrm{Cl}^{-1}\right.$ ). Use of Eq. (2) with the Celtic Sea data gave much lower rates of biomass-specific photosynthesis 0.033 to 0.058 $\mathrm{h}^{-1}$ ) than were obtained from Eq. (1). The use of natural logarithms in the calculation (Eq. 2) is necessitated by the assumed exponential increase of biomass during the incubation, however if biomass does not increase then Eq. (2) is inappropriate. That the volume-specific photosynthesis rate, and by inference phytoplankton biomass, was essentially constant is definitely known for the 26 May experiment in which discrete ${ }^{14} \mathrm{C}$ uptake and particulate ${ }^{14} \mathrm{C}$ accumulation were measured in 
parallel. If the photosynthesis rate was $0.11 \mathrm{~h}^{-1}$, as infered from a comparison of ${ }^{14} \mathrm{C}$ uptake rate with initial biomass, then the discrete ${ }^{14} \mathrm{C}$ uptake rate should have increased by 3 times over $10 \mathrm{~h}$. This is clearly not the case (Fig. 3).

\section{DISCUSSION}

The results presented in the previous section are somewhat paradoxical in that high biomass-specific rates of phytoplankton photosynthesis are accompanied by linear particulate ${ }^{14} \mathrm{C}$ accumulation and apparently static biomass. The problem is one of reconciling high photosynthesis rates with unmeasurable changes in metabolically active biomass. One possible explanation for these observations is that grazing activity by microzooplankton limited the increase of phytoplankton biomass. If, however, microzooplankton grazing can be eliminated as a possible explanation, as appears to be the case for the Celtic Sea spring bloom under consideration, then mechanisms that would contribute to uncoupling of phytoplankton photosynthesis and growth need to be considered. Two possibilities include (1) high respiration of unlabelled carbon by phytoplankton, and/or (2) photosynthate accumulation as an energy storage reserve without net increase in the size of the cell catalytic components. All 3 of these possibilities (i. e. microzooplankton grazing, phytoplankton respiration, and accumulation of energy storage reserves) will be considered in the following discussion.

A simple model of carbon dynamics can be used to theoretically examine the influence of grazing pressure on particulate organic ${ }^{14} \mathrm{C}$ accumulation (Eqs. 3 to 8). In this model, phytoplankton growth is assumed to be exponential with the net growth rate equal to the difference between biomass-specific photosynthesis and grazing rates;

$$
\mathrm{d} P(t) / \mathrm{d} t=(p-g) P(t)
$$

where $P(t)=$ phytoplankton biomass $\left(\mu \mathrm{g} \mathrm{C}^{-1}\right) ; t=$ time (h); $p=$ biomass-specific net photosynthesis rate $\left(\mathrm{h}^{-1}\right)$; $g$ is the biomass-specific loss rate to grazers $\left(\mathrm{h}^{-1}\right)$. The growth rate is given by $\mu=p-g$.

Eq. (3) provides the theoretical basis for interpretation of dilution grazing experiments (Landry \& Hassett 1982). The following discussion examines the implications of using Eq. (3) to interpret the dynamics of ${ }^{14} \mathrm{C}$ accumulation. Integrating Eq. (3) with respect to time yields

$$
P(t)=P_{0} \exp [(p-g) t]
$$

where $P_{0}=$ initial phytoplankton biomass. Particulate ${ }^{14} \mathrm{C}$ accumulation by phytoplankton is assumed to equal net primary production, consistent with direct experimental observations on healthy phytoplankton cultures (Eppley \& Sloan 1965, Ryther \& Menzel 1965), leading to the following equation for changes in phytoplankton ${ }^{14} \mathrm{C}$ content

$$
\mathrm{d} P^{*}(t) / \mathrm{d} t=p P_{0} f \exp (\mu t)-g P^{*}(t)
$$

where $P^{\cdot}(t)={ }^{14} \mathrm{C}$ activity $\left(\mathrm{dpm} l^{-1}\right)$ in the phytoplankton; $f=$ specific activity of total dissolved inorganic carbon ( $\mathrm{dpm} \mu \mathrm{g}^{-1} \mathrm{C}$ ). Integrating Eq. (5) with respect to time yields

$$
P^{*}=P_{0} f[\exp (\mu t)-\exp (-g t)]
$$

The accumulation of organic ${ }^{14} \mathrm{C}$ in microheterotrophs is assumed equal to the product of the grazing rate and assimilation efficiency

$$
\mathrm{d} H^{*}(t) / \mathrm{d} t=\alpha g P^{*}(t)
$$

where $H^{\bullet}(t)={ }^{14} \mathrm{C}$ activity in the microheterotrophs; $\alpha$ $=$ assimilation efficiency (dimensionless). The organic ${ }^{14} \mathrm{C}$ that is not assimilated is assumed to be respired immediately following ingestion. It is possible that a small proportion of ingested carbon may not contribute to either microzooplankton growth or respiration, but is egested (Caron et al. 1985). This possible complication will not be considered further. Subsituting Eq. (6) into Eq. (7) and integrating yields

$$
H^{*}=\left(\alpha g P_{0} f\right)\{[\exp (\mu t)-1] / \mu+[\exp (-g t)-1] / g\}
$$

The total particulate organic ${ }^{14} \mathrm{C}$ production $\left(T^{*}\right)$ is the sum of $P^{*}$ and $H^{*}$;

$$
\begin{aligned}
T^{*}=P_{0} f\{[1+ & (\alpha g / \mu)] \exp (\mu t) \\
& +[\alpha-1] \exp (-g t)-\alpha(1+g / \mu)\}
\end{aligned}
$$

This model is identical in structure to that investigated by Jackson (1983). It differs from that examined by Smith et al. (1984) by neglecting direct loss of ${ }^{14} \mathrm{C}$ from the phytoplankton, and by assuming direct coupling of respiration to assimilation of organic ${ }^{14} \mathrm{C}$ in the microheterotrophs.

Results of a simulation in which $p=0.1 \mathrm{~h}^{-1}\left(2.4 \mathrm{~d}^{-1}\right)$ and $g=0.08,0.04,0.02$ or $0.01 \mathrm{~h}^{-1}$ with $\alpha=0.5$ (Calow 1977) are illustrated in Fig. 4. The model predicts that particulate ${ }^{14} \mathrm{C}$ accumulation will vary greatly with dilution if microbial communities are characterized by high microheterotrophic activity. As discussed by Jackson (1983), this conclusion applies equally to communities in which the interaction between phytoplankton and heterotrophs is either phagotrophic or saprotrophic, Interestingly, particulate ${ }^{14} \mathrm{C}$ accumulates linearly in the undiluted samples characterized by high photosynthesis and grazing rates (Fig. 4). For the assumed photosynthesis rate and high grazing pressure illustrated in Fig. 4 it is unlikely, given typical errors in measurement of ${ }^{14} \mathrm{C}$ activity, that non-linearity in particulate ${ }^{14} \mathrm{C}$ accumulation would be evident in 
undiluted seawater or seawater diluted to $50 \%$ of ambient concentrations. Even in samples diluted to $25 \%$ of ambient concentrations, the upward curvature might be obscured by experimental noise unless incubations are conducted for periods greater than about 12 h. This exceeds the typical duration of the light period in productivity experiments. In retrospect, it appears that particulate ${ }^{14} \mathrm{C}$ accumulation may be a poor variable for examining the influence of grazing on phytoplankton populations. This is especially the case if biomass-specific photosynthesis rates are low. However, these difficulties should not pose major problems for the interpretation of experiments reported in this paper (i.e. Figs. 1 and 2) in which photosynthesis rates were high and incubations were extended to as long as $30 \mathrm{~h}$. The application of the dilution technique under these circumstances suggests that microzooplankton grazers do not play a major role in controlling phytoplankton growth. The use of discrete ${ }^{14} \mathrm{C}$ uptake rates to evaluate changes of metabolically active biomass in dilution experiments supports the conclusion that the activity of microheterotrophs does not have a significant effect on phytoplankton growth or photosynthesis rates. This conclusion is also consistent with the small contribution of apochlorotic nanoplankton to total nanoplankton that has been previously observed in the Celtic Sea (Joint \& Pipe 1984, Joint et al. 1986).

The assumption made in the preceding analysis that ${ }^{14} \mathrm{C}$ accumulation by phytoplankton equals net primary production is loosened, and the possibility that phytoplankton respiration rates are high, is examined by fitting a simple model of intracellular carbon dynamics to the particulate ${ }^{14} \mathrm{C}$ accumulation time-series. The choice of an appropriate model is problematic. Recent studies on cultures of a marine diatom in balanced growth suggest that the substrate for respiration is a small pool of recently labelled compounds (Smith \& Platt 1984, Smith \& Geider 1985). This description, however, may not be appropriate under conditions of non-balanced growth (Smith \& Platt 1984, Smith \& Geider 1985). In particular, a high rate of turnover of intracellular macromolecule pools such as chlorophyll a (Riper et al. 1979) and protein (Richards \& Thurston 1980, Thurston \& Richards 1980) may be a general feature of the metabolic response to a changed environment (Cooke 1981). If a significant turnover of cell resources is characteristic of populations in nature, then account needs to be taken of the contribution of unlabelled 'old' carbon to the pool of respiratory substrates. To accommodate this latter possibility, a model was chosen which describes photosynthesis and respiration of a homogeneous phytoplankton population:

$$
P^{\cdot}=P_{0} f[\exp (\mu t)-\exp (-r t)]
$$

This model has been previously employed in theoreti-

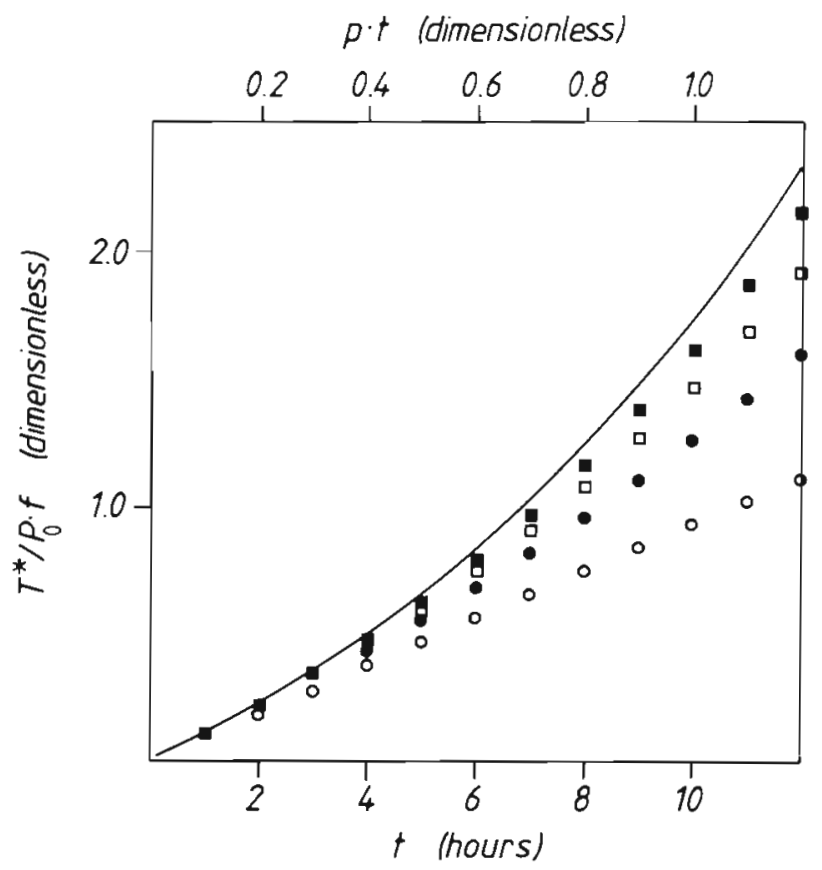

Fig. 4. Time-course of particulate ${ }^{14} \mathrm{C}$ accurnulation predicted by Eq. (9) for $p=0.1 \mathrm{~h}^{-1}, \alpha=0.5$, and $g / p=0.8(0), 0.4(\bullet), 0.2$ $(\because)$, or 0.1 ( $)$. Solid line indicates the accumulation rate in the absence of grazing. The $y$-axis gives relative biomass production where the initial biomass concentration in the ${ }^{14} \mathrm{C}$ incubation container has a value of 1.0

cal studies of the ${ }^{14} \mathrm{C}$ method (Buckingham et al. 1975 , Hobson et al. 1976, Dring \& Jewson 1982, Smith 1982). Note the similarity between Eq. (10) and Eq. (6). In Eq (10) the loss of organic ${ }^{14} \mathrm{C}$ from phytoplankton is attributed to respiration whereas in Eq. (6) it is attributed to grazing by microzooplankton. Despite this similarity in form, the response of the 2 models to dilution is very different. The parameter $r$ in Eq. (10) is independent of dilution, whereas $g$ in Eq. (6) depends linearly on dilution.

Values for the parameters of this model were estimated from non-linear least squares regression analysis using the BMDP program PAR (Dixon 1983). In all cases the initial biomass was obtained from direct counts of cells retained on a $1.0 \mu \mathrm{m}$ Nuclepore filter and values of particulate ${ }^{14} \mathrm{C}$ accumulation were scaled down by a factor of 0.65 to account only for that fraction of photosynthetic biomass retained by a $1.0 \mu \mathrm{m}$ pore size filter. Growth rates in undiluted samples estimated by this approach ranged from 0.01 to $0.05 \mathrm{~h}^{-1}$. On the basis of this analysis, the expected biomass increases range from a low value of $10 \%$ on 25 May to a high of $80 \%$ on 26 May. The $80 \%$ biomass increase was not evident in either chlorophyll $a$, or discrete, short-term ${ }^{14} \mathrm{C}$ uptake rates for the $26 \mathrm{May}$ experiment. Estimates of respiration rate exceed net growth rates by a factor of about 2 to 6 . Biomass-specific photosynthesis rates 
obtained from fitting Eq. (10) to the data were about 30 to $50 \%$ greater than those obtained by used linear regression analysis (Table 2$)$ and initial biomass $(P / B$ in Table 5). In general, the curve-fitting exercise indicates high respiration rates and a low ratio of gross photosynthesis to respiration. Good fit of the observed particulate ${ }^{14} \mathrm{C}$ accumulation time series to Eq. (10) cannot be taken as evidence of the validity of the model. All that can be said is that if Eq. (10) adequately describes the intracellular carbon dynamics, then the estimated parameter values (Table 5) will provide the best description of the data. Is there other evidence to support the conclusion of high phytoplankton respiration rates?

Dark loss of previously fixed organic ${ }^{14} \mathrm{C}$ has been used as a measure of respiration in microplankton communities (Eppley \& Sharp 1976, Smith 1977). Dark loss of organic ${ }^{14} \mathrm{C}$ was measured in 4 experiments (Table 6). Loss rates were calculated as

$$
\text { loss rate }=\left[\ln A_{2} / A_{1}\right] /\left(t_{2}-t_{1}\right)
$$

where $A=$ activity of organic ${ }^{14} \mathrm{C} ; t=$ time and the subscripts refer to observations made at different times. The dark loss rates will not necessarily equal true respiration rates unless the respiring organisms are uniformly labelled. Non-uniformity in distribution of label could result if (1) the preincubation with ${ }^{14} \mathrm{C}$ in the light is not long enough to obtain isotopic equilibrium, (2) non-photosynthesizing phytoplankton are responsible for high respiration, or (3) recent photosynthate is not available for respiration. All 3 of these potential problems will lead to an underestimation of respiration from the dark loss of organic ${ }^{14} \mathrm{C}$. In comparing the dark loss rates with the respiration rates estimated from Eq. (10) it is implicitly assumed that the microheterotrophic contribution to community metabolism is negligible.

Dark loss rates averaged $-0.02 \mathrm{~h}^{-1}$ (i.e. $0.5 \mathrm{~d}^{-1}$ for a

Table 6. Dark loss rates of particulate organic ${ }^{14} \mathrm{C}$. Organic ${ }^{14} \mathrm{C}$ was allowed to accumulate in the light for periods ranging from 12 to $34 \mathrm{~h}$ (labeling period). The loss of organic ${ }^{14} \mathrm{C}$ was measured following a subsequent incubation in darkness. Loss rates with units of inverse time $\left(\mathrm{h}^{-1}\right)$ were calculated as described in the text

\begin{tabular}{|c|c|c|c|}
\hline Date and dilution & $\begin{array}{c}\text { Loss rate } \\
\left(\mathrm{h}^{-1}\right)\end{array}$ & $\begin{array}{l}\text { Labeling } \\
\text { period (h) }\end{array}$ & $\begin{array}{c}\text { Time in dark- } \\
\text { ness }(\mathrm{h})\end{array}$ \\
\hline 25 May $100 \%$ & -0.020 & 12.0 & 10.5 \\
\hline $\begin{array}{r}26 \text { May } 100 \% \\
25 \%\end{array}$ & $\begin{array}{l}-0.014 \\
-0.018\end{array}$ & $\begin{array}{l}12.4 \\
12.4\end{array}$ & $\begin{array}{l}11.0 \\
11.0\end{array}$ \\
\hline $\begin{array}{r}30 \text { May } 100 \% \\
25 \% \\
10 \%\end{array}$ & $\begin{array}{l}-0.033 \\
-0.017 \\
-0.001\end{array}$ & $\begin{array}{l}34.0 \\
34.0 \\
34.0\end{array}$ & $\begin{array}{l}12.8 \\
12.8 \\
12.8\end{array}$ \\
\hline 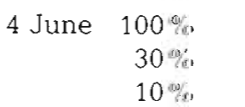 & $\begin{array}{l}-0.084 \\
-0.082 \\
-0.079\end{array}$ & $\begin{array}{l}22.0 \\
22.0 \\
22.0\end{array}$ & $\begin{array}{l}12.5 \\
12.5 \\
12.5\end{array}$ \\
\hline
\end{tabular}

24 h day) for the 25, 26 and 30 May experiments when photosynthesis rates equalled 0.05 to $0.011 \mathrm{~h}^{-1}$ (Table 6). In the 4 June experiment, however, the dark loss rate was considerably higher $\left(-0.08 \mathrm{~h}^{-1}\right)$, and approximately equal to the photosynthesis rate $(P / B=0.09$ $\mathrm{h}^{-1}$ ). Interestingly, the high dark loss rate observed in the 4 June experiment was independent of dilution suggesting that respiration was by phytoplankton.

Only for the 4 June experiment was the measured dark loss rate (Table 6) approximately equal to the respiration rate calculated by fitting Eq. (10) to the particulate ${ }^{14} \mathrm{C}$ accumulation time-series (Table 5). In 3 other experiments, dark loss rates were only 20 to $40 \%$ (Table 6) of the inferred respiration rate (Table 5) indicating that respiration may not always account for the observed descrepancy between photosynthesis and growth rates.

The question still remains of the extent to which dark loss rates can be taken as a measure of respiration in the light. The physiological evidence is equivocal. It is generally thought that light inhibits plant respiratory processes (Graham 1980); however, there are reports of continued mitochondrial respiration in the light (Brown 1953, Bidwell 1977). This respiratory activity, however, need not involve the remineralization of recently labelled organic matter (Bidwell 1977)

One problem with accepting low ratios of photosynthesis to 'dark' respiration rates $(p: r<2)$ calculated from Eq. (10) for the Celtic Sea phytoplankton assemblages is that such low p:r ratios imply negative net production over a $12 \mathrm{~h}: 12 \mathrm{~h}$ light:dark photoperiod. In addition such low values are rarely found for phytoplankton in culture. High p:r ratios of 5 to 10 are found in green algae, diatoms and cyanobacteria, while lower ratios of 2 to 4 are found in dinoflagellates (Dunstan 1973, Humphrey 1975, Raven \& Beardall 1981). In addition, low $p: r$ ratios are often found in cultures maintained under suboptimal conditions for growth, or in species that are characterized by low growth rates. A low $p: r$ ratio is often associated with a decrease in photosynthetic capacity per unit biomass rather than with an increase in biomass-specific respiration rates. Despite the correlation between growth rate and respiration rate in microalgae (Smith 1982), low p:r ratios (i.e. about unity) are not found at high growth rates.

Even if respiratory processes measured by dark loss of organic ${ }^{14} \mathrm{C}$ occur continuously in the light, these rates do not equal the photosynthesis rate during the light period in 3 out of 4 experiments. Thus, there remains a need to account for net photosynthesis in the absence of increases in photosynthetically active biomass. If the phytoplankton are in a 'lag' or acclimation phase because of a change in environmental conditions (such as an increase in photon flux density) following sampling and confinement, then photosynthetically 
active biomass would not be expected to increase immediately. It is necessary to invoke this possibility to explain the results of the 26 May experiment in which high biomass-specific photosynthesis rates did not appear to result in growth (Fig. 3), nor did they appear to be balanced by high respiration rates (Table 5). Unfortunately, direct measurements are not available to test this hypothesis. Indirect evidence to suggest that accumulation of storage products and/or functional, but non-photosynthetic, metabolic machinery is likely to account for the observed kinetics is as follows. Based on a recent review of laboratory investigations (Geider $1987 \mathrm{~b})$, a value for the $\mathrm{C}$ :chl a ratio of about $100 \mathrm{~g} \mathrm{C} \mathrm{g}^{-1}$ chl $a$ is expected for phytoplankton in nutrient-sufficient, balanced growth at a temperature of $11^{\circ} \mathrm{C}$ and photon flux density of $140 \mu \mathrm{mol} \mathrm{m} \mathrm{m}^{-2} \mathrm{~s}^{-1}$. As noted previously, initial C:chl a ratios from 20 to $55 \mathrm{~g} \mathrm{C} \mathrm{g}^{-1}$ chl a were obtained for the Celtic Sea nanoplankton. The difference between the initial value of $\mathrm{C}$ : chl $\mathrm{a}$ and the expected value under the incubation conditions would allow for 2 to 5 -fold increase in phytoplankton carbon before the synthesis of chlorophyll $a$ and associated components of the photosynthetic apparatus would commence (Geider \& Platt 1986). Interestingly, in experiments employing ${ }^{14} \mathrm{C}$ labeling of phytoplankton carbon and chlorophyll $a$, Welschmeyer \& Lorenzen (1984) found increases in C:chl a during incubations of natural phytoplankton assemblages. These increases in C:chl a were particularly evident at high light levels (Welschmeyer \& Lorenzen 1984).

In conclusion, observations that dilution with filtered seawater did not influence ${ }^{14} \mathrm{C}$ uptake dynamics indicate that microzooplankton grazing was not an important determinant of phytoplankton photosynthesis and growth in the Celtic Sea phytoplankton assemblage under investigation. The explanation for the observed high, yet constant, biomass-specific rates of particulate ${ }^{14} \mathrm{C}$ accumulation may lie in a combination of high phytoplankton respiration rates and the allocation of recent photosynthate to energy storage reserves rather than to growth-related processes.

Acknowledgements. Work at the University of Birmingham. was supported by NERC grant number GR3/5900 awarded to B.S.C. Leadbeater. I thank Dr I. Joint for providing an opportunity to participate in the NERC research cruise to the Celtic Sea on the RRS 'Charles Darwin', and Dr B. S. C. Leadbeater and Ms. Alison Edwards for assistance at sea with the ${ }^{14} \mathrm{C}$ uptake experiments. I also thank Dr B. S. C. Leadbeater for critically reading and commenting on the manuscript.

\section{LITERATURE CITED}

Azam, F., Fenchel, T., Field, J. G., Gray, J. S., Meyer-Reil, L.A., Thingstad, F. (1983). The ecological role of water column microbes in the sea. Mar. Ecol. Prog. Ser 10:257-263
Bidwell, R. R. S. (1977). Photosynthesis and respiration in freshwater algae. Can. J. Bot. 55: 809-818

Bratbak, G., Dundas, I. (1984). Bacterial dry matter content and biomass estimates. Appl. environ. Microbiol. 48: $755-757$

Brown, A. H. (1953). The effects of light on respiration using isotopically enriched oxygen. Am. J. Bot. 40: 719-729

Buckingham, S., Walters, C. J., Kleiber, P. (1975). A procedure for estimating gross production, net production and algal carbon content using ${ }^{14} \mathrm{C}$. Verh. int. Verein. theor. angew. Limnol. 19: 32-38

Burkill, P. H. (1982). Ciliates and other microplankton components of a nearshore food-web: standing stock and production processes. Ann. Inst. océanogr., Paris 58: 335-350

Calow, P. (1977). Conversion efficiencies in heterotrophic organisms. Biol. Rev, 52: 385-409

Caron, D. A., Goldman, J. C., Andersen, O. K., Dennett, M. R. (1985). Nutrient cycling in a microflagellate food chain: II Population dynamics and carbon cycling. Mar. Ecol. Prog Ser. 24: 243-254

Cooke, R. J. (1981). Protein degradation in plants. Sci. Prog. Oxf. 67: 461-480

Davies, J. M. Williams, P. J. LeB. (1984). Verification of ${ }^{14} \mathrm{C}$ and $\mathrm{O}_{2}$ primary organic production measurements using an enclosed ecosystem. J. Plankton Res. 6: 457-474

Dixon, W. J. (1983). BMDP statistical software 1983, printing and additions. University of California Press, London

Douglas, D. J. (1984). Microautoradiography-based enumeration of photosynthetic picoplankton with estimates of carbon-specific growth rates. Mar. Ecol. Prog. Ser. 14 223-228

Dring, M. J., Jewson, D. H. (1982). What does ${ }^{14} \mathrm{C}$ uptake by phytoplankton really measure? A theoretical modelling approach. Proc. R. Soc. Lond. B 214: 351-368

Dunstan, W. M. (1973). A comparison of the photosynthesislight intensity relationship in phylogenetically different marine microalgae. J. exp. mar. Biol. Ecol. 13: 181-187

Eppley, R. W. (1968). An incubation method for estimating the carbon content of phytoplankton in natural samples. Limnol. Oceanogr. 13: 574-582

Eppley, R. W. (1972). Temperature and phytoplankton growth in the sea. Fish. Bull. U. S. 70: 1063-1085

Eppley, R. W., Reid, F. M. H., Strickland, J. D. R. (1970). The ecology of the plankton off La Jolla, California, in the period April through September 1967. Part III. Estimates of phytoplankton crop size, growth rate and primary production. Bull. Scripps. Inst. Oceanogr. 17: 33-42

Eppley, R. W., Sharp, J. H. (1976). Photosynthetic measurements in the central North Pacific: the dark loss of carbon in 24 hour incubations. Limnol. Oceanogr. 20: 981-987

Eppley, R. W., Sloan, P. R. (1965). Carbon balance experiments with marine phytoplankton. J. Fish. Res. Bd Can. 22: $1083-1097$

Furnas, M. J. (1982). Growth rates of summer nanoplankton $(<10 \mu \mathrm{m})$ populations in lower Narragansett Bay, Rhode Island, U.S.A. Mar. Biol. 70: 105-115

Furnas, M. J. (1983). Community structure, bıomass and productivity of size fractionated summer phytoplankton populations in lower Narragansett Bay, Rhode Island. J Plankton Res. 5: 637-655

Geider, R. J. (1987a). An improved method for the observation and enumeration of heterotrophic and photoautotrophic microplankton. J. exp. mar. Biol. Ecol, 110: 19-25

Geider, R. J. (1987b). Light and temperature dependence of the carbon to chlorophyll a ratio in microalgae and cyanobacteria: implications for physiology and ecology of phytoplankton. New Phytol. 106: 1-34 
Geider, R. J., Platt, T. (1986). A mechanistic model of photoadaptation in microalgae. Mar. Ecol. Prog. Ser. 30: 85-92

Goldman, J. C., Taylor, C. D., Glibert, P. M. (1981). Nonlinear time-course uptake of carbon and ammonium by marine phytoplankton. Mar. Ecol. Prog. Ser. 6: 137-148

Graham, D. (1980). Effects of light on 'dark' respiration. In: Davies, D. D. (ed.) The biochemistry of plants, Vol. 2. Academic Press, New York, p. 525-579

Harding, L. W., Jr, Prézelin, B. B., Sweeney, B. M., Cox, J. L. (1982). Diel oscillations of photosynthesis-irradiance (P-1) relationship in natural assemblages of phytoplankton. Mar. Biol. 67: 167-178

Hobson, L. A., Morris, W. J., Pirquet, K. T (1976). Theoretical and experimental analysis of the ${ }^{14} \mathrm{C}$ technique and its use in studies of primary production. J. Fish. Res. Bd Can. 33: $1715-1721$

Holm-Hansen, O., Lorenzen, C. J., Holmes, R. W., Strickland, J. D. H. (1965). Fluorometric determination of chlorophyll. J. Cons. int. Explor. Mer 30: 3-15

Humphrey, G. F. (1975). The photosynthesis:respiration rate of some unicellular marine algae. J. exp. mar. Biol. Ecol. 18: $111-119$

Jackson, G. A. (1983). Zooplankton grazing effects on ${ }^{14} \mathrm{C}$ based phytoplankton production measurements: a theoretical study. J. Plankton Res. 5: 83-94

Jensen, L. M. (1983). Phytoplankton release of extracellular organic carbon, molecular weight composition, and bacterial assimilation. Mar. Ecol. Prog. Ser. 11: 39-48

Johnson, P. W., Xu, Huai-Shu, Sieburth, J. McN. (1982). The utilization of chroococcoid cyanobacteria by marine protozooplankters but not by calanoid copepods. Ann. Inst. océanogr., Paris 58: 297-308

Joint, I. R., Owens, N. J. P., Pomroy, A. J. (1986). Seasonal production of photosynthetic picoplankton and nanoplankton in the Celtic Sea. Mar. Ecol. Prog. Ser. 28 251-258

Joint, I. R., Pipe, R. K. (1984). An electron microscope study of a natural population of picoplankton from the Celtic Sea. Mar. Ecol. Prog. Ser. 20: 113-118

Joint, I. R., Pomroy, A. J. (1983). Production of picoplankton and nanoplankton in the Celtic Sea. Mar. Biol. 77: 19-27

Kana, T. M., Watts, J. L., Glibert, P. M. (1985). Diel periodicity in the photosynthetic capacity of coastal and offshore phytoplankton assemblages. Mar. Ecol. Prog. Ser. 25: 131-139

Keller, M. D., Mague, T. H., Badenhausen, M., Glover, H. (1982). Seasonal variations in the production and consumption of amino acids by coastal microplankton. Estuar. coast. Shelf Sci. 15: 301-315

Kirchman, D., Ducklow, H., Mitchell, R. (1982). Estimates of bacterial growth from changes in uptake rates and biomass. Appl. environ. Microbiol. 44: 1296-1307

Lancelot, C. (1979). Gross excretion rates of natural marine phytoplankton and heterotrophic uptake of excreted products in the southern North Sea, as determined by shortterm kinetics. Mar. Ecol. Prog. Ser. 1: 179-186

Landry, M. R., Haas, L. W., Fagerness, V. L. (1984). Dynamics of microbial plankton communities: experiments in Kaneohe Bay, Hawaii. Mar. Ecol. Prog. Ser. 16: 127-133

Landry, M. R., Hassett, R. P. (1982). Estimating the grazing impact of marine microzooplankton. Mar. Biol. 67: 283-288

Laws, E. A., Redalje, D. G., Haas, L. W., Bienfang, P. K., Eppley, R. W., Harrison, W G., Karl, M., Marra, J. (1984). High phytoplankton growth and production rates in oligotrophic Hawaiian coastal waters. Limnol. Oceanogr. 29: 1161-1169
Li, W. K. W. (1984). Microbial uptake of radiolabelled substrates: estimates of growth rates from time course measurements. Appl. environ. Microbiol. 47: 184-192

Li, W. K. W., Goldman, J. C. (1981). Problems in estimating growth rates of marine phytoplankton from short-term ${ }^{14} \mathrm{C}$ assays. Microb. Ecol. 7: 113-121

Li, W K. W., Harrison, W. G. (1982). Carbon flow into endproducts of photosynthesis in short and long incubations of a natural phytoplankton population. Mar. Biol. 72: $175-182$

Li, W. K. W., Subba-Roa, D. V., Harrison, W. G., Smith, J. C., Cullen, J. J., Irwin, B., Platt, T. (1983). Autotrophic picoplankton in the tropical ocean. Science 219: 292-295

MacCaull, W. A., Platt, T. (1977). Diel variations in the photosynthetic parameters of coastal marine phytoplankton. Limnol. Oceanogr. 22: 723-731

Mague, T. H., Friberg, E., Hughes, D. J., Morris, I. (1980). Extracellular release of carbon by marine phytoplankton: a physiological approach. Limnol. Oceanogr. 25: 262-279

Marra, J., Landriau, G., Jr., Ducklow, H. W. (1981). Tracer kinetics and plankton rate processes in oligotrophic oceans. Mar. Biol. Lett. 2: 215-223

Morgan, K. C., Kalff, J. (1979). Effect of light and temperature interactions on growth of Cryptomonas erosa (Cryptophyceae). J. Phycol. 15: 127-134

Peterson, B. J. (1978). Radiocarbon uptake, its relation to net particulate carbon production. Limnol. Oceanogr. 23: $179-184$

Peterson, B. J. (1980). Aquatic primary productivity and the ${ }^{14} \mathrm{C}-\mathrm{CO}_{2}$ method: a history of the productivity problem. Ann. Rev. Ecol. Syst. 11. 359-385

Platt, T., Subba-Rao, D. V., Irwin, B. (1983). Photosynthesis of picoplankton in the oligotrophic ocean. Nature, Lond. 310 : $702-704$

Putt, M., Prézelin, B. B. (1985). Observations of diel patterns of photosynthesis in cyanobacteria and nanoplankton in the Santa Barbara Channel during 'El Nino'. J. Plankton Res. 7: 779-790

Raven, J. A., Beardall, J. (1981). Respiration and photorespiration. Can. Bull. Fish. Aquat. Sci. 210: 55-82

Richards, L., Thurston, C. F. (1980). Protein turnover in Chlorella fusca var. vacuolate: measurement of the overall rate of intracellular protein degradation using isotope exchange with water. J. gen. Microbiol. 121: 49-61

Riper, D. M., Owens, T. G., Falkowski, P. G. (1979). Chlorophyll turnover in Sketetonema costatum, a marine plankton diatom. Plant. Physiol. 64: 49-54

Ryther, J. H., Menzel, D. W. (1965). Comparison of the ${ }^{14} \mathrm{C}-$ technique with direct measurement of photosynthetic carbon fixation. Limnol. Oceanogr. 10: 490-492

Sheldon, R. W., Sutcliffe, W. H., Jr (1978). Generation times of three hours for the Sargasso Sea microplankton determined by ATP analysis. Limnol. Oceanogr. 23: 1051-1055

Sherr, E. B., Sherr, B. F. (1987). High rates of consumption of bacteria by pelagic ciliates. Nature, Lond. 325: 710-711

Sieburth, J. McN, Davis, P. G. (1982). The role of heterotrophic nanoplankton in the grazing and nurturing of planktonic bacteria in the Sargasso and Caribbean Seas. Ann. Inst. océanogr., Paris 58: 285-296

Sieburth, J. McN., Smetacek, V., Lenz, J. (1978). Pelagic ecosystem structure: heterotrophic compartments of the plankton and their relationship to plankton size fractions. Limnol. Oceangr. 23: 1256-1263

Smith, R. E. H. (1982). The estimation of phytoplankton production and excretion by carbon-14. Mar. Biol. Let. 3: 325-334 
Smith, R. E. H., Geider, R. J. (1985). Kinetics of intracellular carbon allocation in a marine diatom. J. exp. mar. Biol. Ecol. 9: 191-210

Smith, R. E. H., Geider, R. J., Platt, T (1984). Microplankton productivity in the oligotrophic ocean. Nature, Lond. 311 : 252-254

Smith, R. E. H., Platt, T. (1984). Carbon exchange and ${ }^{14} \mathrm{C}$ tracer methods in a nitrogen-limited diatom, Thalassiosira pseudonana. Mar. Ecol. Prog. Ser. 16: 75-87

Smith, W O. (1977). The respiration of photosynthetic carbon in eutrophic areas of the ocean. Deep Sea Res. 35: 557-565

Strathmann, R. (1967). Estimating the organic carbon content of phytoplankton from cell volume or plasma volume. Limnol. Oceanogr. 12: 411-418

Taguchi, S. (1976). Relationships between photosynthesis and cell size of marine diatoms. J Phycol. 12: 185-189

Takahashi, M., Bienfang, P. K. (1983). Size structure of phytoplankton biomass and photosynthesis in subtropical Hawaiian waters. Mar. Biol. 76: 203-211

Thurston, C. F., Richards, L. (1980). Protein turnover in
Chlorella fusca var. vacuolata: detection of a rapidly degraded class of protein in growing and non-growing cells. J. gen. Microbiol. 121:63-68

Verity, P. G. (1986). Grazing of nanoplankton by microzooplankton in Narragansett Bay. Mar. Ecol. Prog. Ser. 29: $105-115$

Welschmeyer, N. A., Lorenzen, C. J. (1984). Carbon-14 labeling of phytoplankton carbon and chlorophyll a carbon: determination of specific growth rates. Limnol. Oceanogr. 29: $135-145$

Williams, P. J. LeB. (1981). Incorporation of microheterotrophic processes into the classical paradigm of the planktonic food web. Kieler Meeresforsch. 5: 1-28

Williams, P. J. LeB., Heinemann, K. R., Marra, J, Purdie, D. A (1983). Comparison of ${ }^{14} \mathrm{C}$ and $\mathrm{O}_{2}$ measurements of phytoplankton in oligotrophic waters. Nature, Lond. 305: 49-50

Williams, P. J. LeB., Raine, R. C. I., Bryan, J. R. (1979) Agreement between the ${ }^{14} \mathrm{C}$ and oxygen methods of measuring phytoplankton production: reassessment of the photosynthetic quotient. Oceanologica Acta 2: 411-416

This article was presented by Dr B. L. Bayne; it was accepted for printing on January 4, 1988 